\title{
BEING OURSELVES: IMMIGRANT CULTURE AND SELF- IDENTIFICATION AMONG YOUNG HAITIANS IN MONTRÉAL
}

\author{
Scooter Pégram \\ Indiana University Northwest
}

Since the early 1960s, large numbers of Haitians have emigrated from their native island nation. Changes in federal immigration legislation in the 1970s in both the United States and Canada enabled immigrants of colour a facilitated entry into the two countries, and this factor contributed to the arrival of Haitians to the North American continent. These newcomers primarily settled in cities along the eastern seaboard, in Boston, Miami, Montréal and New York. The initial motivator of this two-wave Haitian migration was the extreme political persecution that existed in Haiti under the iron-fisted rule of the Duvalier dictatorships and their secret police (popularly known as the "tontons macoutes") over a thirty year period from the late 1950 s to the mid 1980s.

\section{Background}

The first wave of Haitian immigrants to Montréal consisted primarily of professionals from the Haitian élite class. These immigrants spoke fluent French, were often university educated, and many fled or were forced into exile due to intense harrying by 
the brutal dictatorial regime of François Duvalier. The total number of these arrivals was quite small, but their contributions to their adopted home were extremely significant as they often assumed the same type of jobs that they had left behind in Haiti; occupying positions that fit their occupational training (Dejean, 1978).

Starting in the mid 1970s, the social demographic of arriving Haitians to Canada began to change. This second wave of Haitian immigrants hailed principally from the working classes, and they fled Haiti in large numbers for many of the same reasons as the first group. However, these newcomers differed starkly from their predecessors, as they were much more diverse in their characteristics. For example, this second group of Haitian immigrants often did not possess the same grasp of French as the first wave; hence they encountered language difficulties and financial hardship which led to downward mobility upon their arrival (Dejean, 1990). While all Haitians speak Créole, this new group of Haitian immigrants spoke that language almost exclusively. While the first wave of immigrants fled Haiti and landed in Canada as business or independent arrivals, the subsequent arrivals were often asylum seekers who lacked the professional skills of their predecessors.

Concerning demographics, the Montréal region serves as the magnet and principal destination in Canada for all arrivals from Haiiti. More than 95\% of all Haitians in Canada live in Québec, with over $90 \%$ of them residing in the Montréal metropolitan area (Dejean, 1990). Haitians labour in many diverse employment sectors in Québec society, from blue collar to professional. Haitians are also extremely visible in Québécois culture: working as journalists and broadcasters in the media, contributing to the arts, as well as contributing to pop culture via the entertainment industry. It is important to note that this type of visibility does not exist in other areas of the North American Haitian Diaspora. For example, there are few, if any Haitians who have achieved similar success in the United States; despite the fact that the New York City area alone has a Haitian population estimated to be over 500,000 people (aside, perhaps, from Wyclef Jean and a few other exceptions). 
This diverging detail regarding Haitians in the two countries can be attributed to several factors: higher rates of discrimination again people of colour in the United States than Canada; the Canadian government policy of State multiculturalism that actively promotes diversity in the country; and the fact that Québec is a Francophone society into which Créole speaking Haitians can integrate with relative ease. Concerning the latter reason, because French is the official language of Haiti and is the primary vernacular used by the Haitian élite, it has long been considered as a useful device in order to achieve upward mobility among all Haitians, despite an overall lack of comprehension in French by the vast majority of the population (Dejean, 1978, 1990).

The principal goal of the present paper is to gain an understanding of how identity and an immigrant culture is forged, expressed and ultimately transformed among young Haitians in Montréal. This particular analysis makes references to three factors: self-identification, their attachments to the host (majority) society, and proficiency in the heritage and majority languages.

\section{Identity and Immigrant Youth}

Although young Haitians are a very visible part of the Québec mosaic, few studies exist that concentrate on this segment of the community and little interest has been given to the ever-growing Haitian community of Montréal. However, there are some notable investigations involving the integration of young Haitians that merit our attention.

For example, Stepick (1998) researches the large Haitian community of Miami from an anthropological and sociological perspective, examining various social, communal and cultural links between Haitians and Cubans in South Florida. Stepick (1998, 2001) argues that Haitians in Miami suffer from intense discrimination on the part of the three majority cultures surrounding them (Cuban / Latino, white, and African-American), and this social exclusion causes a type of identity crisis among Haitian youth. In his findings regarding young Haitian high school students in Miami, Stepick (1998:62-69, 2001) maintains that the many young Haitians would do anything to avoid being labelled "Haitian," as they felt that this designation would hurt them socially and economically vis-à-vis their peers. While perhaps not every single high school 
aged Haitian student adopts this policy of shedding the heritage culture in favour of the majority culture, Stepick (1998, 2001) discovers that the majority of young Haitians indeed become "Americanized" in language and tradition very quickly. Stepick (1998:69, 2001) contends that young Haitians have little social incentive or reasoning to draw attention to their Haitian heritage, as they often prefer to blend in with African-Americans as a means of confronting the immense discrimination and prejudice directed towards them. Simply put, according to Stepick $(1998,2001)$ it is more desirable for young Haitians in Miami to assume AfricanAmerican cultural norms and traits than to label themselves as "Haitian" and face possible intolerance from other cultural groups.

In a qualitative survey of Haitian high school students in Miami, Stepick $(1998: 62,2001)$ found that a majority of respondents claim to have been discriminated against in various facets because of their Haitian heritage. Many of these students complained that simply being known as a "Haitian" damaged their social status and proved to be a reason for cultural bias and second-class treatment. Stepick (1998:62-69, 2001) contends that many Haitian high school students in Miami who assimilate into inner city African-American culture are reluctant concerning this decision. Consequently, an identity crisis occurs due to the fact that these youth are not fully certain to which culture they belong. Due to these facts, Stepick (1998:78) argues that within a few short years, in their struggle for social acceptance, young Haitians in Miami will achieve what for other groups took three generations: rejecting their cultural roots and embracing American culture, especially African-American traditions.

The city of Montréal is the second most important Frenchspeaking municipality in the world (after Paris) and is Québec's largest and most important urban area. Montréal plays a major role in the development of Québec; the sole area of North America where French is spoken as the principal language. That said, Montréal is a city that was constructed and colonized by the British, and to this very day it has a substantial English-speaking minority population. Furthermore, and perhaps most importantly, Montréal is a multicultural, cosmopolitan metropolis and an international city. 
Due to the fact that French-speaking Québec finds itself in a minority position in English-speaking North America, immigrant youth in Québec encounter much pressure to abandon their cultural heritage and assimilate into the majority Francophone culture. Arnopoulos (1980) and Bauer (1994) argue that although this notion may not be an institutionalized policy set forth by the Québec government, immigrants are expected to assimilate into the fabric of majority society. Pressure to shed one's heritage language (in favour of French) places immigrants in a subordinate position in terms of their capacity and social standing. Since French-speaking Québec is itself of marginal importance on the North American continent in terms of language and culture, this complexity adds another ingredient into the social turmoil felt by youth from immigrant communities in the province (Arnopoulos, 1980). However, due to their similarities with the Québécois majority in terms of religion (Catholicism), and in lesser extent to language (French), young Haitians could find themselves in an advantaged position vis-à-vis the majority culture concerning their social standing in reference to other immigrant groups. Unfortunately, despite these possibilities, young Haitians remain marginalized by Québec society.

\section{Immigrant Culture}

Tse (1997) contends that children of first-generation immigrants in North American society are frequently caught between two, and often three communities: the community of the heritage country that was left behind; the local heritage community of their parents and / or families; and the dominant (majority) community surrounding them. Méthot (1995:34) and Micone $(1981,1990,1995)$ define the mingling of these three realities as "la culture immigrée" or immigrant culture. Because immigrant youth are caught in the mire of a unique social construct encompassing three societal communities, Micone (1990, 1995) argues that they often incorporate aspects of each to form a fourth distinct cultural community of their own: a distinct "immigrant culture." In this sense, young immigrants are transforming themselves by creating their own distinct traditions by incorporating elements from the duelling majority / minority fact of Québec, as well as 
their own heritage designators. The present paper examines how young Haitians in Montréal identify themselves in reference to the above questions by analyzing some of the reasoning behind their choices.

Identity, in regards to immigrantyouth in Québec and elsewhere, is sometimes considered as a social pathology in terms of selfidentification, and Abou (1986) and Meintel (1992, 1995) argue that immigrant youth sometimes suffer from problems related to their identity due to these conflicting associations. Freisan (1993), Micone (1981, 1990, 1995) and Stepick (1998, 2001) examine topics relating to social integration and adaptation in order to explain the consequences of this type of a conflicting "double identity" association found among immigrant youth in Canada, especially within the province of Québec. In one sense, immigrant youth have the benefit of sharing values with the host society in addition to the heritage society, affording them the better of two opportunities. For example, Tse (1997) argues that possessing a double identity could be a tremendous advantage for immigrant youth as they have the ability to move between two distinctive communities (host to heritage, minority to majority, and vice-versa). However, Abou (1986), Méthot (1995) and Stepick (1998, 2001) assert that possessing multiple identities may also be a divisive factor that contributes to a complicated identity designation that could lead to a personality crisis and cultural confusion.

Micone (1981, 1990, 1995) and Méthot (1995) further contend that the notion of having a double-identity does not always have positive consequences, as it sometimes results in the formation of an immigrant culture as a reactionary method used by youth as a manner in which to create their own niche out of the surrounding social disorientation. In the context of Québec, Micone (1981, 1990, 1995) and Méthot (1995) contend that the birth of an immigrant culture is the direct result of misunderstandings by the provincial government towards the various ethnocultural groups living in the province. Despite some positive steps taken by the government to help facilitate the transition of cultural communities into Québec majority society, Arnopoulos (1980), Bauer (1994) and Micone $(1990,1995)$ argue that a general comprehension of the immigrant experience and the needs of the Québec immigrant community is lacking. 
Dreidger (1978), Meintel (1992), Tse (1997) and Micone (1990, 1995) argue to differing degrees that although immigrants and ethnocultural groups belong to a certain cultural assemblage that can be held together by language, history, appearance (etc.), these groups often evolve, modify and transform themselves once they are within a society where they are dominated (culturally, socially, politically). Due to various degrees of this dominance, ethnocultural minority groups may soon diverge from their heritage culture (Tse, 1997).

In the 1970s, the new nationalist manifestation of Québec became firmly entrenched within the Canadian federation, finally allowing the province an opportunity to address issues dealing with the minority fact within it (Arnopoulos, 1980). After the adoption of the Charter of the French Language in 1977 (known as Bill 101) many in nationalists in Québec were confronted with the compulsory reality of integrating the province's cultural communities into the majority Francophone culture (Arnopoulos, 1980). While the language legislation established French as the official language of Québec, Bauer (1994) maintains that cultural communities within the province tend to assimilate into majority society at a much slower pace than others elsewhere in North America. Castonguay (1992) and Bauer (1994) maintain that Québec's cultural communities possess a cultural persistence that is unmatched in other large immigrant centres on the North American continent due to the unique social construct of the province (i.e. Francophones as the majority culture in Québec while being in a minority position on a continent which is overwhelmingly Anglophone). Although the language legislation has not fully assimilated the cultural communities of the province (since 28 years is not quite enough to erase a generational pattern), it has succeeded on several fronts. For example, by forcing parents to send their children to French schools, immigrant children are adopting French as their principal language of communication at a remarkable rate.

In this sense, youth from ethnocultural communities are able to attach themselves to the French-speaking majority, although this attachment is not a total or complete one. Among others, Arnopoulos (1980), Meintel (1992, 1995) and Micone (1995, 1999) argue that immigrant youth prefer to align themselves to 
the majority community in their own fashion, without omitting or forgetting their own language and culture in the process. Thus, young immigrants might be developing into Francophones as far as language is concerned, however they are not becoming Québécois as far as identity is concerned. Instead, these youth are creating a new distinct cultural identity that fits their needs where they do not completely abandon their ethnocultural heritage; while at the same time they incorporate certain aspects of the majority Québec culture, such as language, pop culture, and fashion. Studies conducted by Arnopoulos (1980), Fleras (1992), Taylor (1994) and Méthot (1995) indicate that Montréal is a multidimensional society where immigrant youth have the capability to combine ethnic associations without settling on one single ethnic culture, majority or minority.

Identity among ethnocultural minority groups can be described in different manners. For example, Tse (1997:7-10) argues that the image or perception that certain individuals have towards their group and their own self-perceived identity directly influences their feelings of belonging to that assemblage. Therefore, the impressions that Haitian youth have of themselves concerning their self-perceived identity can emphasize their positive or negative reactions towards the heritage and host communities. It is essential to understand how Haitians identify with the images and representations of the majority culture that surrounds them. Due to conflicting surroundings, Haitian youth are often caught between the traditional heritage culture of their parents and the host culture of their peers. From a Québec point of view, Micone $(1990,1995)$ contends that immigrant society in the province has little or nothing to do with the societies from the heritage countries of the various ethnic groups in question. Furthermore, Micone $(1990,1995)$ maintains that this new culture also differs from the dominant majority group.

In the following sections, we will determine how Haitian youth identify themselves. As well, we will discern whether or not Haitians feel included as being a part of majority society. Lastly, we will also investigate how the importance of language, both the majority language (French) and the language of the heritage group (Créole) may forge their identification of being Haitian or Québécois. 


\section{Self-Identification}

Since Haitians are a visible minority within the Québec mosaic who shares a few common denominators with the dominant majority group (e.g. a similar linguistic history, a common religion, and French colonization), we must begin our presentation by looking at how Haitian youth choose to identify themselves. To the question "how do you identify yourself," respondents were given four categories from which to select their answer: "Haitian (only) above all other classifications; Haitian first, Québécois second; Québécois first, Haitian second"; and "Québécois (only) above all other classifications." Figure 1 shows the findings of this inquiry.

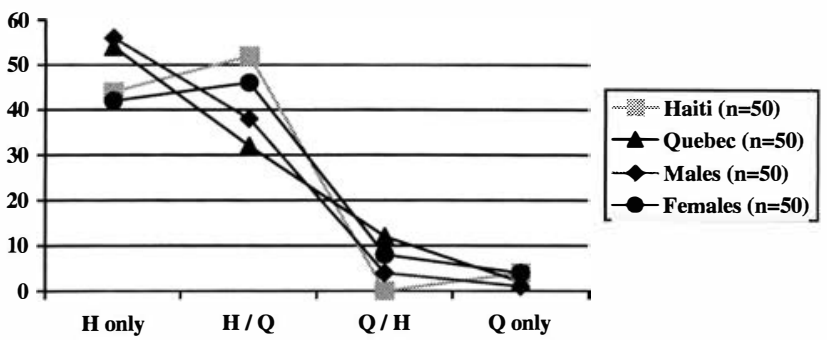

The data from Figure 1 show that a strong majority of Haitian youth $(91 \%)$ regardless of birthplace identify themselves either as "Haitian only" or "Haitian first, Québécois second." When the data are broken down into individual categories, the findings from Figure 1 also show that a slight majority of Québec-born Haitians $(54 \%)$ identify themselves as being "Haitian only." A slight minority of Haitian-born respondents (44\%) share the same identification. A statistically significant difference was found between the two groups of respondents based on birthplace, and this difference is due to the fact that more Québec-born respondents (54\%) indicate that they identify themselves as "Haitian-only" than do Haitian-born respondents (44\%). This interesting distinction can be further characterized and understood when one considers that the proximity and strength of the North American Haitian Diaspora (especially New York City) strongly influences Haitians in Montréal. It is also important to note that many respondents from both groups indicate that they felt more "Haitian" than "Québécois." Based on this data (and contrary to Stepick's research on young Haitians in Miami), we maintain that Haitian youth in Montréal do 
not distance themselves from their ethnocultural origin, regardless of their place of birth or total overall years spent in Québec. However, will these findings differ in regards to gender?

Concerning gender differences, the findings from Figure 1 demonstrate that more males (56\%) than females (42\%) identify themselves as being "Haitian only." When the identification includes being "Québécois" along with "Haitian," the findings illustrate that that more females choose this classification than males ("Haitian first / Québécois second," females 46\%, males 38\%). Few respondents of either gender choose to identify themselves as "Québécois" either first (males 4\%, females 8\%), or outright (males $2 \%$, females $4 \%$ ), although it should be noted that twice the number of females choose these classifications over their male brethren. This difference between genders is directly related to the fact that females tend to pull toward the societal norm in cultural surveys and they tend to be more susceptible to social change. In this case the norm means identifying oneself less as being fully "Haitian" and more of being at least partially "Québécois." Few of the total ensemble of respondents of either group identify themselves as "Québécois" either "first" or "outright," although it should be noted from examining the data regarding gender from Figure 1 that some Québec-born women choose this classification, again demonstrating their tendency to pull toward the societal and cultural norm.

\section{Societal Inclusion}

An important goal of this research was to discern whether or not young Haitians view themselves as being equal partners in Québec. Quite often in the past, the term "Québécois" has been used pejoratively in various nationalist gatherings to describe only white Francophones living in Québec, excluding, or outright dismissing immigrants as the "other"; too unusual to be considered a real part of Québec society. Due to this past exclusion, many immigrant communities in the province frequently feel excluded from the majority culture, arguing that the term "Québécois" simply does not include them since many Francophones would never consider them as "Québécois" at all, despite any good intentions on their part (Arnopoulos, 1980; Meintel, 1992; Bauer, 
1994; Méthot, 1995). Because Haitians share a few common denominators with the dominant culture, what are their feelings concerning this subject? Respondents were asked if they felt included as being "Québécois" when they heard the moniker "nous autres les Québécois" (we Québécois), and they were given four choices from which to choose: "never, at times, often, or always." The results of this inquiry are shown in Figure 2.

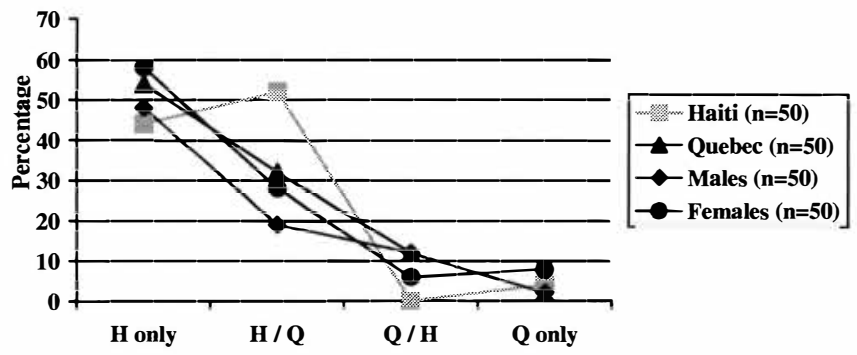

Figure 2. When you hear 'nous autres les Québécois,' do you feel included? By birthplace and gender

When combining the "at times" and "often" categories, the data from Figure 2 show that $44 \%$ of Haitian-born respondents feel "Québécois" at least some of the time, compared to only $40 \%$ of Québec-born respondents. This distinction can perhaps be explained considering that Haitian-born respondents come from a society with a legacy of harsh governmental repression. Therefore, Haitian-born respondents may feel a much stronger bond towards the host society, whereas many Haitians born in Québec may not since they have faced issues relating to discrimination and exclusion from the majority culture since their childhood. Furthermore, it can be argued that Haitian-born respondents find Québec to be a free and open society that welcomed them, so their feeling of being "Québécois" is perhaps more clearly understood than Québecborn respondents, some of whom have had to deal with social exclusion their entire lives. A majority of respondents from both groups remark that they "never" feel included as "Québécois." These findings are hardly surprising considering that immigrants in Québec are often ignored by the provincial government, except during times where their votes are needed (such as during provincial election campaigns). 
Regarding gender distinctions, the findings from Figure 2 show that that a large number of respondents, including a majority of women, indicate that they never feel included as "Québécois." When the data from Figure 2 are further broken down by gender, it is interesting to note that more females (58\%) than males $(48 \%)$ indicate that they never feel included as "Québécois." This can be explained due to the fact that Haitian women can be classified as a "triple minority" in Québec society. Haitian women are not only isolated from the majority society due to social differences of language and race, but also they are also socially isolated due to their gender. Despite their willingness to identify themselves at least partially as "Québécois," (as the data show in Figure 1) the findings from Figure 2 show that young Haitian females by and large do not feel included as equal partners in Québec. Figure 2 shows that more males (12\%) often feel included as "Québécois" than females $(6 \%)$. This finding highlights the ability of males to fit at least partially into the majority society despite the fact that they tend to not identify themselves as being "Québécois," as the data from Figure 1 show. However, it is nonetheless interesting to note that when comparing only the female respondents from both groups, $60 \%$ of Haitian-born females indicate that they never feel "Québécois," compared with 46\% of Québec-born females. Although no statistically significant difference was found between males and females, a difference was found between the two groups of female respondents regarding this question. One explanation for this is the fact that Haitian-born females are faced with a language barrier which adds to their social sensitivity, whereas Québec-born females generally do not face this same social dilemma. Twenty-eight percent of Haitian-born females feel Québécois "at times" and the same percentage of Québecborn respondents' share that view. Québec-born young Haitian women are also more likely to feel more included as "Québécois" than their Haitian-born brethren, with the latter group feeling the greater effects of being in a triple minority position. As was the case with the male respondents, Figure 2 shows that few females feel "Québécois" either "often," or "always." 


\section{Language Shift}

Until the 1950s, little effort was made to convert Créole from a primarily oral language into a written form. Even today in contemporary Haïti, Créole is considered to be an oral language, as the educational emphasis remains on the acquisition of written and oral French in the majority of the country's educational facilities. However, in many schools, written Créole is taught, although acquiring proficiency in French remains the priority. All of the Haitian youth who were surveyed in the present research, whether Québec-born or Haitian-born, report that they speak at least some Créole, with all stating that their heritage language is a very important part of their overall identity. Obviously, their ability and proficiency in spoken Créole varies from person to person. Concerning language ability in the heritage language, respondents were asked to assess their proficiency on a Likert scale from one to five, consolidated here as "low" (levels one and two), "average" (level three), and "high" (levels four and five); respondents chose the number which best reflects their spoken proficiency in the language (with "one" having the weakest proficiency, and "five" the strongest). Figure 3 presents these findings.

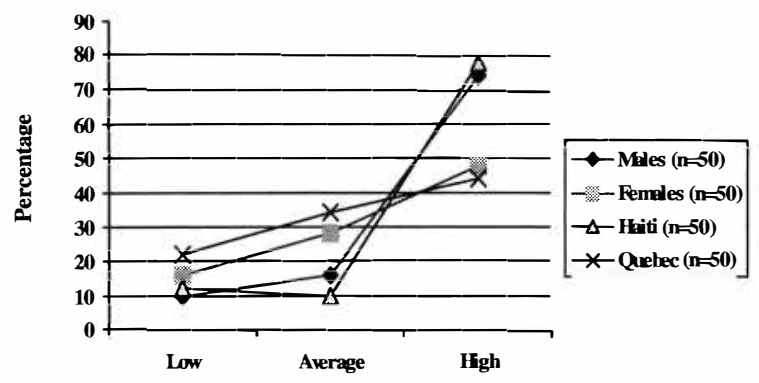

Figure 3. Knowledge of Spoken Créole, by birthplace and gender

The data from Figure 3 indicate that respondents who were born in Haïti have stronger proficiency in spoken Créole than Québecborn counterparts, as the former grew up in a Créole-speaking environment where it was the dominant culture and language, and the latter did not. A majority of Haitian-born respondents (78\%) and males (74\%) indicate that they speak Créole at a "high" level. In addition, a smaller number of females (44\%) and Québec-born 
respondents (48\%) indicate that they speak Créole at a "high" level, and their abilities in the heritage language can be traced at similar levels (primarily at the "average" and "low" levels). Furthermore, the data for Haitian-born respondents and males also follow nearly the same percentages.

Regarding gender differences, the findings from Figure 3 illustrate that spoken ability in Créole among males consequently boosts the number of Haitian-born respondents' abilities in the heritage language, and the same can be said of females, who pull the Québec-born respondents' numbers down to a lower ability level mirroring the results in the other categories as well. As Figure 3 illustrates, gender differences directly influence the data as the large number of males and females responding in a certain manner affect the overall response percentages in the birthplace category.

\section{Analysis}

In terms of self-identification, young Haitians do not tend to identify themselves as "Québécois." A majority of Haitians identify themselves as either "Haitian first," or "above all" other classifications, regardless of their birthplace or gender. This shows that Haitian youth remain conscious and connected to the ethnocultural heritage as far as their feelings of self-identification is concerned. The cultural and linguistic vitality of young Haitians is very high due to the strength and proximity of the North American Haitian Diaspora (especially New York City), and because of this reality, there is less need for many youth to identify fully with the Québécois majority culture. As well, because the Haitian community in Québec is very visible through media, pop culture, the entertainment industry, and the arts (and is somewhat accepted by the dominant majority culture), there is less reason for young Haitians to try and "prove their worth" (i.e. assimilate towards the majority culture) in the province.

More males identify themselves as "Haitian only" than do females, whereas more females identify themselves as "Haitian first, Québécois second," or "Québécois" either "first" or "outright." As females are more likely to identify themselves (at least partially) with the majority culture, they are moving towards the societal norm. Therefore, we maintain that this partial identification with 
the majority society is one way in which young Haitian females may improve their social status and achieve (or strive for) a sort of upward mobility since females tend to be more status conscious than men.

Regardless of how young Haitians identify themselves (males or females), the majority feel that they are not included as being "Québécois" or considered as equal partners by the majority culture regardless of their good faith. A larger number of females than males do not feel included as "Québécois" due to the fact that their triple minority status (minority in language, gender, and race) and subordinate social status makes them feel excluded. Both of these notions separate young Haitian females from the majority culture, despite their own willingness and desire to selfidentify with it.

Tse (1997) and Loslier (1998) argue that the more members of minority ethnocultural groups find themselves lost among the masses of the majority culture, the more they desire to rediscover their own heritage and history. Tse (1997:13-17) argues that this identity transformation tends to occur when youth move from high school into university study or when they become young adults, as this is a time when minority youth obtain more independence from their family and peers.

Our findings indicate that Haitian youth are generally at the apex of this transition, either currently experiencing the changes of rediscovering their ethnocultural heritage or having already transformed. At times, Haitians, as well as other immigrants, play down their separate identity and assimilate themselves at one point (at least in part) into the larger, more dominant Québécois society; while at other times, young Haitians choose to emphasise their ethnocultural distinctiveness.

While successive Québec premiers and administrations by and large have historically ignored the immigrant fact of Québec, they have nonetheless invested much energy into the integration of newcomers and their families into Québec society, thereby anticipating that these groups will fully attach themselves to the French language as they become assimilated into the majority culture (Bauer, 1994). Since Haitians share many similar traits with the dominant majority culture in Québec, one could assume 
that their identification with Québec majority society would be more significant than that of other immigrant groups due to their historical affection for the French language.

Given four choices from which to choose, all Haitian youth surveyed in this study were asked how they identify themselves. Both groups of respondents according to birthplace overwhelmingly indicate that they are either "Haitian" above all other classifications or "Haitian first, Québécois second." Few young Haitians declared themselves to be either "Québécois outright" or "Québécois first, Haitian second." Even more unexpected is the fact that a large number Québec-born Haitians identify themselves as "Haitian only." These results not only conflict with the proposed hypotheses, they also run in contrast to the Québec government's own desire to integrate immigrants into Québec society.

There are several explanations for this. For example, Tse (1997) argues that ethnocultural heritage is often rediscovered in the years of young adulthood, often resulting in renewed strong feelings towards the heritage group. As well, the fact that Haitians are a visible minority tends to isolate them further from the dominant culture, and they are not always allowed full access as equal participants in majority society, even if they have the desire to integrate. Many people from immigrant communities believe that Québécois typically tend to be ignorant of cultural minorities, and this ignorance may nullify any potential or desired attachment that young Haitians may have constructed towards the dominant culture.

In analysing gender differences, our findings show that more males than females identify themselves as "Haitian only," while females identify themselves as either "Haitian first / Québécois second," or "Québécois first or outright." There are three explanations for this:

1. Women are more aware of their societal status than men.

2. Women are in a subordinate social position (both in majority and minority society), and aligning themselves with the Québécois majority culture serves as possible way in which to obtain a sort of upward mobility and status change.

3. Because males have higher linguistic abilities in French, language may be an important factor in their self-identification 
as Haitian since language and culture can be directly linked. This notion is less apparent among females from cultural communities, due to their secondary status as a "triple minority" (as a woman, as a person of colour in a minority position, as a speaker of a different maternal language).

Therefore, in certain respects, young Haitian females are pulling towards the majority culture rather than maintaining certain cultural distinctions. This cultural shift among females is due to the fact that they are viewed as a "triple minority," and one way in which to shed (or lessen) this status is to adopt certain cultural traits and / behaviours of the dominant culture. This type of social movement (as shown above) occurs quite frequently among women of colour from ethnocultural communities (Pedraza, 1991; Afshar and Maynard, 1994; Brettal and Simon, 1996).

In general, our findings coincide with Micone's (1990, 1995) assessment of the Allophone fact of Québec. Despite the fact that the Québec government imposes language legislation on its ethnocultural communities, and this legislation does integrate young immigrants into the Francophone sector a linguistic sense, cultural integration is another subject and our findings clearly indicate this reality. As we mentioned earlier, ethnocultural groups in the province tend to view the term "Québécois" as being reserved for the white Francophone majority at the exclusion of everyone else, regardless of ability in French or participation in the general society. Some examples of this omission include the annual parade on the day of "la fête nationale" (24th June, which until very recently excluded full participation in the celebration from members of minority organizations), and remarks by politicians such as the former Premier of Québec Jacques Parizeau on the defeat of the "oui" the night of the 1995 Québec referendum.1

Further proof of these feelings of being isolated and rejected from the majority culture is discovered when inquiring whether or not Haitian youth feel included as "Québécois" when they hear this term being used by others. Majorities from both groups of respondents according to birthplace indicate that they do not feel "Québécois" at all when they hear others use this moniker. Although some respondents may feel at least partially "Québécois" when they classify themselves, they do not feel included when 
they hear others use the term. Interestingly, more females than males indicate that they never feel included as "Québécois," and more males than females indicate that they feel "Québécois" either "often" or "always," although the total number of respondents in these two categories is minimal. Once again, because females possess "triple minority" status in Québec (language, gender and race), they feel isolated from the surrounding society, thereby believing that they are not included as a part of it. This fact occurs despite the fact that more females than males identify themselves as being "Haitian and Québécois" (or "Québécois" either "first" or "outright"). No matter their good intentions concerning selfidentification, this finding shows that females identify themselves one way, while at the same time indicating that they feel that the majority culture identifies and excludes them in another.

Since the 1980s, the concept of one's ethnicity has played an increasingly important role in the lives of young Haitians in Québec. Haitian youth have become more conscious of their ethnocultural diversity in Québec, and many would like the majority culture to become aware of this fact as well, being that they see the future not as monocultural but rather multicultural. The strains between young Haitians' hopes for a new life and the reality of their constant struggle for identity will continue to create a distinct immigrant culture among this sector of Québec society, regardless of their birthplace. Haitian youth in Québec have strong social ties amongst themselves and with other youth hailing from different ethnocultural groups, as well as possessing a strong individual fortitude. Although not every young Haitian has the same social resources from which to choose, nearly all reaffirm pride in their ethnocultural heritage, no matter how removed they seem to be from Haïti. Although many young Haitians will conclude that issues relating to racism and discrimination are keeping them from reaching the pinnacle of Québec society, others will dismiss this notion and continue to increase their own unique brand of visibility in the new, multicultural Québec.

\section{References}

ABOU, S. (1986). L'identité culturelle. Paris: Anthropos. AFSHAR, H. and MAYNARD, M., editors, (1994). The Dynamics 
of Race and Gender: Some Feminist Interventions. London: Taylor and Francis.

ARNOPOULOS, S. (1980). The English Fact in Québec. Montréal: McGill University Press.

BAUER, J. (1994). Les minorités au Québec. Montréal: Boréal.

BRETTAL, C. and SIMON, R. (1986). Immigrant Migration: The Female Experience. Totowa: Rowman and Allenheld.

BOURHIS, R. (1984). Conflict and Language Planning in Québec. London: Clevedon.

BOYD, M. (1992). "Gender Issues in Immigration and Language Fluency," from: Immigration, Language and Ethnic Issues: Canada and the United States, editor Barry Chiswick, Washington, DC: American Enterprise Institute, pp. 305-372.

CASTONGUAY, C. (1992). "L'orientation linguistique des allophones à Montréal." From: Cahiers québécois de démographie, vol 21, no. 2, pp. 95-118.

DEJEAN, P. (1978). Les Haïtiens au Québec. Montréal: Presses de I'Université du Québec à Montréal.

—_. (1990). D'Haïti au Québec. Montréal: CIDIHCA.

DREIDGER, L. (1978). The Canadian Ethnic Mosaic: A Quest for Identity.

Toronto: McClelland and Stewart.

FLERAS, A. (1992). Multiculturalism in Canada: The Challenge of Diversity. Toronto: Thompson Canada Ltd.

FRIESAN, J. (1993). When Cultures Clash. Calgary: Detselig Enterprises.

LOSLIER, S. (1998). Des relations interculturelles: Du roman à la réalité. Montréal: Liber.

MEINTEL, D. (1987). Le quartier Côte-des-Neiges à Montréal: Les interfaces de la pluriethnicité. Montréal: L'Harmattan.

—. (1992). L'identité ethnique chez de jeunes Montréalais d'origine immigrée.

Montréal: Sociologie et sociétés.

—. (1995). Les jeunes d'origine immigrée: Rapports familiaux et les transitions de vie; le cas des jeunes Chiliens, Grecs, Portugais, Salvadoriens, et Vietnamiens. Québec: Ministère des communautés culturelles.

MÉTHOT, C. (1995). Du Viêt-nam au Québec: La valse 
des identités. Montréal: Institut québécois de recherche sur la culture.

MICONE, M. (1981). "La culture immigrée réduite au silence" from Dérives, no. 17, pp. 21-25.

—_. (1984). Gens du silence. Montréal: Éditions Guernica.

—. (1990). "Occulation et émergence de la culture immigrée," from Impressions, pp. 4-7.

—. (1995). "De l'assimilation à la culture immigrée" from Possibles, vol. 14, no. 3, pp. 139-146.

PEDRAZA, S. (1991). "Women and Migration: The Social Consequences of Gender" From: Annual Review of Sociology, volume 17, pp. 303-325.

STEPICK, A. (1998). Pride against Prejudice: Haitians in the United States. Boston: Allyn and Bacon.

—. (2001). "Shifting Identities and Intergenerational Conflict: Growing Up Haitian in Miami." In: Rumbaut, G. and Portes, A. (eds.) Ethnicities: Children of Immigrants in America. Berkeley: University of California Press, pp. 229-266.

TAYLOR, C. (1994). Multiculturalisme: Différence et démocratie. Paris: Aubier.

TSE, L. (1997). Ethnic Identity and the Role of the Heritage Language. Los Angeles: University of Southern California.

VALDMAN, A. (1975). "The Language Situation in Haïti." From Vera Rubin and Richard Schaedel, editors, The Haitian Potential: Research and Resources of Haïti. New York: Teacher's College Press, pp. 62-83.

\section{Notes}

1 While speaking live on Canadian national television and also on live world-wide coverage on the American network CNN, former Québec premier Jacques Parizeau blamed the loss of the "oui" during the 1995 Québec referendum on sovereignty on "money and the ethnic vote," stating: "C'est vrai qu'on était battu, en effet par quoi? Par l'argent et des votes ethnique essentiellement." (It is true that we have been defeated, in effect by what? By money and ethnic votes, essentially). 